\title{
Fat supramolecular structure in fat-filled dairy powders: A tool to adjust spray-drying temperatures
}

\author{
Marie-Laure Vignolles ${ }^{1,2}$, Christelle Lopez $^{1,2}$, Cécile Le Floch-Fouéré ${ }^{1,2}$, \\ Jean-Jacques EhrhardT ${ }^{3}$, Serge MÉJEAN ${ }^{1,2}$, Romain JEANTET ${ }^{1,2}$, Pierre SCHUCK ${ }^{1,2 *}$ \\ ${ }^{1}$ INRA, UMR1253, F-35000 Rennes, France \\ ${ }^{2}$ Agrocampus Ouest, UMR1253, F-35000 Rennes, France \\ ${ }^{3}$ CNRS, Nancy-Université, UMR7564, Laboratoire de Chimie Physique et de Microbiologie \\ pour l'Environnement, F-54600 Villers-lès-Nancy, France
}

\author{
Received 29 June 2009 - Revised 30 October 2009 - Accepted 1st December 2009 \\ Published online 19 January 2010
}

\begin{abstract}
Despite the increasing economic impact of fat-filled dairy powders, their manufacture is still empirical. The aim of the study was to understand the mechanisms responsible for fat supramolecular structure in such a dry matrix. For the purpose, emulsions were obtained under controlled manufacturing conditions. Then, they were dried under different inlet air temperatures, leading to different drying kinetics. Fat droplet size was determined in both emulsions and powders. Free fat and surface fat were assessed to characterize fat in the resulting powders. Confocal laser scanning microscopy was used to characterize fat supramolecular structure in situ in the powder particles. Results showed that fat supramolecular structure in fat-filled dairy powders was connected with drying air temperatures, not necessarily with drying kinetics. Inlet air temperature and consequently temperature of the drying droplet had the most significant influence. Such a study considering drying air temperatures and kinetics is essential in elucidating the mechanisms of free fat formation and the presence of fat at the surface of powder particles. Mechanisms underlying fat supramolecular structure in fat-filled dairy powders are proposed: They can be used as a tool to adjust spray-drying air temperatures and kinetics.
\end{abstract}

spray drying / free fat / surface composition / microstructure / mechanism

\begin{abstract}
摘要 - 根据加脂乳粉中脂肪分子结构调整喷雾干燥的温度。尽管加脂乳粉的经济效益不断 增加, 但是加脂乳粉的工业化生产完全是一种经验式的生产。本文目的是研究在加脂乳粉 基质中脂肪超分子结构形成机制。基于这一目的，在特定条件下制备乳浊液，然后将乳浊 液在不同的进口空气温度下干燥，产生了不同的干燥动力学。分别测定了乳浊液和乳粉的 脂肪液滴尺寸。根据游离脂肪表面脂肪来评价最终乳粉脂肪的特性。采用激光共聚焦显微 镜观测了乳粉中原位上的脂肪超分子结构。实验结果表明加脂乳粉中脂肪超分子结构与干 燥空气的温度有关, 而与干燥动力学无关。液滴的进口空气温度和干燥温度对其影响最大。 研究证明干燥空气温度和干燥动力学可以用来解释游离脂肪和干粉颗粒表面脂肪的形成机制。 因此, 在加脂乳粉工业生产中, 可以根据脂肪超分子结构形成的机制来调整喷雾干燥的温 度和干燥动力学。
\end{abstract}

\section{喷雾干燥 / 游离脂肪 / 表面组成 / 微观结构 / 机制}

*Corresponding author (通讯作者): Pierre.Schuck@rennes.inra.fr 
Résumé - Structure supramoléculaire de la matière grasse dans les poudres enrichies : un outil de décision pour ajuster les températures de séchage. Malgré l'intérêt économique croissant pour les poudres laitières enrichies en matière grasse, leur fabrication reste empirique à ce jour. L'objectif de cette étude est de comprendre les mécanismes sous-jacents à la structuration supramoléculaire de la matière grasse dans ce type de poudre. Pour cela, des émulsions ont été fabriquées dans des conditions maitrisées. Elles ont ensuite été séchées avec différentes températures d'air d'entrée, donnant lieu à différentes cinétiques de séchage. La taille des gouttelettes de matière grasse a été mesurée dans les émulsions et les poudres réhydratées. La matière grasse libre et la matière grasse de surface ont été mesurées pour caractériser la matière grasse dans les poudres. La microscopie confocale à balayage laser a été utilisée pour caractériser la structure supramoléculaire de la matière grasse in situ dans les grains de poudre. Les résultats montrent que la structure supramoléculaire de la matière grasse dans les poudres enrichies est corrélée aux températures d'air de séchage, mais pas systématiquement aux cinétiques de séchage. La température d'air d'entrée et par là, la température de la gouttelette de produit en train de sécher, ont l'influence la plus significative. Une telle étude des températures d'air et des cinétiques de séchage est essentielle dans la compréhension des mécanismes de formation de la matière grasse libre et la présence de matière grasse en surface des grains de poudres. Les mécanismes de formation de la structure supramoléculaire de la matière grasse dans les poudres enrichies sont proposés. Ils peuvent être utilisés comme un outil de décision pour orienter les températures d'air et les cinétiques de séchage.

séchage par atomisation / matière grasse libre / composition de surface / microstructure / mécanisme

\section{INTRODUCTION}

Fat supramolecular structure largely determines the quality of fat-filled dairy powders. Given the growing economic and scientific interest for fat-filled powders, it is essential to understand the mechanisms underlying the formation of fat supramolecular structure in fat-filled dairy powders. Fat supramolecular structure includes both fat location (inner or at the surface of powder particles) and fat arrangement (free or globular and droplet size). Fat-filled dairy powders represent a wide range of products such as whole milk powder, cream powder, whey derivates and dairy ingredients enriched with milk fat and mainly with vegetable oils. Their diversified applications require a number of specific physical properties. The literature was first focused on the free fat content and its negative effects on powder physical properties, such as rehydration, flowability and oxidation stability [5, 7, 14, 18]. Conversely, in the case of chocolate processing, a high free fat content is required to lower the viscosity of the mass $[2,19,27]$. The investigation of the surface composition was recently achieved by Fäldt et al. [11], who adapted X-ray photoelectron spectroscopy (XPS) to the study of dairy powders. Since then, the technique has been largely used and the surface composition was related to powder physical properties such as wettability, flowability and stickiness $[13,18,25,30,31,39]$. Few studies considered the influence of fat droplet size and the measurement method was either laser light scattering [15, 18, 29, 39] or, more arguably, image analysis of phase-contrast light micrographs [12, 21].

However, a few studies focused on the mechanisms of the formation of fat supramolecular structure within powder particles. This can be studied by varying the drying kinetics, i.e. using drying air temperatures. The postulate is that it would affect the rate of formation of a dry crust or skin at the surface of the drying droplet, and subsequently, the distribution of components (including surface fat) and the possible release of free fat. Several studies showed that higher inlet air temperatures led to a smaller free fat content in the powder or to a better retention in the case of volatile compounds [3, 7, 17]. 
However, contradictory results were found by Sloth Hansen [34] and no effect was observed by Tamsma et al. [35] with low inlet air temperatures. More recently, Kim et al. [23-25] published an interesting series of three papers on the mechanisms of surface development in powder particles. They showed that the surface composition of milk powders was largely determined during the spray-drying process and that less redistribution of fat and protein occurred at the surface for high drying air temperature. However, the authors did not mention the considerable energetic losses that are usually observed in spray-driers at the pilot scale [41]. Consequently, the inlet air temperature considered by the authors, measured after the air heater, was probably overestimated and drying droplets underwent lower drying conditions.

The literature review showed that further investigations would be useful about the mechanisms of the formation of fat supramolecular structure in a fat-filled dairy powder. The aims of this study were (i) to investigate fat supramolecular structure in a fat-filled dairy powder manufactured under controlled conditions, in relation to spraydrying parameters and (ii) to propose the possible mechanisms responsible for the structure of fat.

The experiments were performed in a pilot-scale spray-drier that was more flexible to produce small quantities of samples with different drying parameters. Moreover, we did not want to test the physical properties of these powders, thus the granulation step was not required. From our previous study, a formulation was selected to stand below the saturation zone for the formation of free fat and surface fat, and thus, to highlight differences between the samples [38]. If not, these fat supramolecular structures would have reached their maximum values and interpretation would have been difficult. In the present work, amorphous lactose was preferred to crystallized lactose in order to avoid the presence of lactose crystals before drying, which are widely known to promote free fat $[1,10,26]$.

\section{MATERIALS AND METHODS}

\subsection{Materials}

Sunflower oil was "Cœur de tournesol", a commercial product of Lesieur (Asnièressur-Seine, France). Ultra low-heat skim milk powder was obtained as described in Schuck et al. [33]. Edible lactose was purchased from LACTOSERUM-France (Baleycourt, France).

Petroleum ether $\left(40-60{ }^{\circ} \mathrm{C}\right.$ boiling point) of analytical grade was obtained from Carlo Erba Reagents (Val-de-Reuil, France). Ethylenediamine tetraacetic acid (EDTA) and sodium dodecyl sulfate (SDS) were purchased from VWR-Prolabo (Fontenaysous-Bois, France). Nile blue chloride and Fast Green FCF were obtained from Sigma-Aldrich (St. Louis, USA), and polyethylene glycol of molecular weight 200 (PEG 200) was obtained from Fluka (Fluka-Sigma-Aldrich, St. Louis, USA).

\subsection{Methods}

Methods are summarized hereinafter when identical to those previously detailed elsewhere [37, 39]. Sampling was realized after (i) homogenization, (ii) spray atomization (i.e. after flowing through the spray nozzle) and (iii) spray-drying.

\subsubsection{Preparation of emulsions and powders}

A mix was prepared with $135 \mathrm{~g} \cdot \mathrm{kg}^{-1}$ protein and $100 \mathrm{~g} \cdot \mathrm{kg}^{-1}$ fat, leading to a protein: fat ratio of 1.35 in accordance with previous experiments [38]. Amorphous lactose was

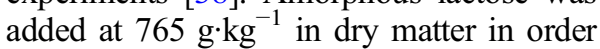
to adjust the protein content. To keep lactose in its amorphous form, the total solids content was only $200 \mathrm{~g} \cdot \mathrm{kg}^{-1}$ in the initial 
Table I. Experimental and calculated parameters used for drying, and corresponding free fat content and surface composition of the powders.

\begin{tabular}{|c|c|c|c|c|c|c|c|c|c|c|}
\hline \multirow[t]{2}{*}{$\begin{array}{l}T_{\text {inlet }} \\
\left({ }^{\circ} \mathrm{C}\right)\end{array}$} & \multirow[t]{2}{*}{$\begin{array}{c}T_{\text {outlet }} \\
\left({ }^{\circ} \mathrm{C}\right)\end{array}$} & \multirow[t]{2}{*}{$\begin{array}{l}\Delta T_{\text {air }}{ }^{1} \\
\left({ }^{\circ} \mathrm{C}\right)\end{array}$} & \multirow[t]{2}{*}{$\begin{array}{c}T_{\text {droplet }^{2}} \\
\left({ }^{\circ} \mathrm{C}\right)\end{array}$} & \multirow[t]{2}{*}{$\begin{array}{c}\Delta T_{\text {droplet }}{ }^{3} \\
\left({ }^{\circ} \mathrm{C}\right)\end{array}$} & \multirow[t]{2}{*}{$\begin{array}{c}\mathrm{RDK}^{4} \\
(\%)\end{array}$} & \multirow[t]{2}{*}{$\begin{array}{l}\text { Feeding rate } \\
\left(\mathrm{kg} \cdot \mathrm{h}^{-1}\right)\end{array}$} & \multirow[t]{2}{*}{$\begin{array}{l}\text { Free fat } \\
\left(\mathrm{g} \cdot \mathrm{kg}^{-1} \text { of }\right. \\
\text { total fat })\end{array}$} & \multicolumn{3}{|c|}{$\begin{array}{l}\text { Surface composition } \\
\text { (\% surface area of } \\
\text { powder particles) }\end{array}$} \\
\hline & & & & & & & & Fat & Protein & Lactose \\
\hline 255 & 105 & 150 & 53 & 52 & 87 & 3.0 & 8.8 & 19 & 53 & 28 \\
\hline 225 & 110 & 115 & 50 & 60 & 100 & 1.8 & 10.7 & 17 & 56 & 27 \\
\hline 225 & 105 & 120 & 50 & 55 & 92 & 3.0 & 10.7 & 16 & 56 & 28 \\
\hline 200 & 100 & 100 & 48 & 52 & 87 & 1.8 & 11.5 & 16 & 56 & 29 \\
\hline 200 & 90 & 110 & 48 & 42 & 70 & 3.0 & 10.9 & 13 & 59 & 28 \\
\hline 180 & 95 & 85 & 45 & 50 & 83 & 1.8 & 12.8 & 16 & 56 & 28 \\
\hline 180 & 80 & 100 & 45 & 35 & 58 & 3.0 & 12.1 & 12 & 58 & 29 \\
\hline
\end{tabular}

${ }^{1} \Delta T_{\text {air }}=T_{\text {inlet }}-T_{\text {outlet }}$.

${ }^{2}$ Theoretical wet temperature of the drying droplet, calculated from the enthalpic diagram for an absolute humidity of $1 \mathrm{~g} \cdot \mathrm{kg}^{-1}$ of water in dry air.

${ }^{3} \Delta T_{\text {droplet }}=T_{\text {outlet }}-T_{\text {droplet }}$.

${ }^{4} \mathrm{RDK}=\Delta T_{\text {droplet }} /$ maximum $\Delta T_{\text {droplet }}$.

preparation, leading to a lactose content clearly below the saturation concentration.

The mix was homogenized at $16 \mathrm{MPa}$ in the first stage and $4 \mathrm{MPa}$ in the second stage using an APV Rannie LAB 12/51 H homogenizer (Assistance Techniques Spéciales, Moissy Cramayel, France). The emulsion was immediately spray-dried in a pilot-scale MOBILE MINOR ${ }^{\mathrm{TM}}$ spray-drier, MM-PSR type (GEA Niro A/S, Søeborg, Denmark), equipped with a bifluid spray nozzle (orifice diameter: $0.80 \mathrm{~mm}$ ). The maximum evaporation rate was $3 \mathrm{~kg} \cdot \mathrm{h}^{-1}$. A Watson-Marlow peristaltic pump, type 520S (Watson-Marlow, Gambais, France), fed the emulsion to the spray-drying chamber, with a feeding rate of 1.8 and $3 \mathrm{~kg} \cdot \mathrm{h}^{-1}$. Inlet air humidity was controlled and adjusted by a Munters dehumidifier, M210 type (Munters Europe AB, Sollentuna, Sweden) at $1{\mathrm{~g} \cdot \mathrm{kg}^{-1}}^{-1}$ of water in dry air. The inlet and outlet air temperatures $\left(T_{\text {inlet }}\right.$ and $\left.T_{\text {outlet }}\right)$ were selected after preliminary experiments, in order to have two feeding rates and six air temperature intervals within the spray-drying chamber $\left(\Delta T_{\text {air }}\right)$. The theoretical wet-bulb temperature of the drying droplet $\left(T_{\text {droplet }}\right)$ was calculated from the $T_{\text {inlet }}$ and the enthalpic diagram for an absolute humidity of $1 \mathrm{~g} \cdot \mathrm{kg}^{-1}$ of water in dry air. The drying droplet temperature interval within the spray-drying chamber $\left(\Delta T_{\text {droplet }}\right)$ was the difference between $T_{\text {outlet }}$ and $T_{\text {droplet. }}$ The relative drying kinetic (RDK) was calculated as follows (\%):

$$
\mathrm{RDK}=\frac{\Delta T_{\text {droplet }}}{\text { maximum } \Delta T_{\text {droplet }}} .
$$

Table I summarizes the experimental and calculated parameters. The maximum $\Delta T_{\text {droplet }}$ is $60{ }^{\circ} \mathrm{C}$, which corresponds to an RDK of $100 \%$ in our experiments.

There was no replication of the powder production trials: the process was assumed to be controlled, referring to preliminary experiments.

\subsubsection{Free fat quantification in powders}

Free fat was recovered after two successive solvent extractions with petroleum ether. 


\subsubsection{Elemental surface composition determination in powders}

The elemental surface composition of the powders (analysis depth $<10 \mathrm{~nm}$ ) was measured by XPS. The instrument and the parameters used for analysis and processing have been described in a previous paper by Gaiani et al. [13]. The elemental composition of the pure components was estimated by XPS. The values used in the calculations were (in atomic concentration \%): sunflower oil - C 90.8, O 9.2; micellar casein - C 70.2, $\mathrm{O}$ 17.2, N 12.6; whey proteins - C 68.1, $\mathrm{O} 16.6, \mathrm{~N} 15.3$; and alpha-lactose monohydrate - C 55.3, O 44.7 .

\subsubsection{Fat droplet size measurements in emulsions and rehydrated powders}

Size distributions of fat droplets were obtained from laser light scattering measurements. Then, the volume-weighted average diameter of fat droplets $\left(d_{43}\right)$ was calculated by the software as follows:

$$
d_{43}=\frac{\sum_{\mathrm{i}} n_{\mathrm{i}} d_{\mathrm{i}}^{4}}{\sum_{\mathrm{i}} n_{\mathrm{i}} d_{\mathrm{i}}^{3}},
$$

where $n_{\mathrm{i}}$ is the particle number of average diameter $d_{\mathrm{i}} \cdot d(0.9)$ was the 90 th percentile of volume-weighted diameters, i.e. $90 \%$ of the volume of fat droplets had a diameter below this value.

EDTA and SDS were used to dissociate casein micelles and bridged-flocculated fat droplets (by displacing protein from the interface), respectively.

\subsubsection{Microstructural observation of the powders}

In situ microstructural analysis of powder particles was performed by confocal laser scanning microscopy (CLSM) using a Zeiss LSM 510 META upright confocal microscope (Carl Zeiss, Germany). Nile blue chloride and Fast Green FCF fluorescent dyes (both at a concentration of $0.1 \mathrm{~g} \cdot \mathrm{L}^{-1}$ in PEG 200) were used to label fat and protein, respectively. Approximately $10 \mu \mathrm{m}$ of PEG 200 and $2 \mu \mathrm{m}$ of each dye preparation were added on a concave microscope slide. Then, a few powder particles were added to the mounting medium with the dyes. A 2-h labeling was realized at $4{ }^{\circ} \mathrm{C}$ to avoid rehydration of the powder particles. Observations were performed with a plan-apochromal $100 \times / 1.4$ oil immersion objective. An Argon/2 laser and a He-Ne2 laser operating at excitation wavelengths of 488 and $633 \mathrm{~nm}$ were used for Nile blue chloride and Fast Green FCF, respectively. Each micrograph was the average of eight pictures of the sample.

\subsubsection{Statistical analysis}

Data were statistically analyzed using the $\mathrm{R}$ software (version 2.2.0), with the "stats" package (R Foundation for Statistical Computing, Vienna, Austria).

\section{RESULTS AND DISCUSSION}

\subsection{The free fat content decreases with increasing drying air temperatures}

The free fat content was quantified in the powders with a solvent extraction method, to test whether spray-drying conditions had an influence on it or not. Free fat had been previously defined as non-globular fat or non-encapsulated fat $[28,36]$.

All powders included free fat (Tab. I), despite the homogenization step and the low total fat content $\left(100 \mathrm{~g} \cdot \mathrm{kg}^{-1}\right.$ in dry matter). It confirmed previous observations for powders manufactured in a higher scale pilot plant (Bionov, France), where free fat contents were in the same order of magnitude [38]. Hence, the Minor ${ }^{\mathrm{TM}}$ pilot-scale dryer was a relevant model to study the 
Table II. Effects of spray-drying conditions on fat droplet size, free fat content and surface composition of powder particles.

\begin{tabular}{|c|c|c|c|c|c|c|c|}
\hline \multirow[t]{3}{*}{ Effect $^{1}$} & \multirow[t]{3}{*}{$\begin{array}{l}\text { Free fat }\left(\mathrm{g} \cdot \mathrm{kg}^{-1} \text { of }\right. \\
\text { total fat })\end{array}$} & \multicolumn{5}{|c|}{$\begin{array}{l}\text { Surface composition (\% surface area } \\
\text { of powder particles) }\end{array}$} & \multirow[t]{3}{*}{$\begin{array}{l}\text { Fat droplet } \\
\operatorname{size}^{6}(\mu \mathrm{m})\end{array}$} \\
\hline & & \multicolumn{3}{|c|}{ Fat } & \multirow[t]{2}{*}{ Protein } & \multirow[t]{2}{*}{ Lactose } & \\
\hline & & Total & Free & Droplets & & & \\
\hline$T_{\text {inlet }}\left({ }^{\circ} \mathrm{C}\right)$ & $-0.0444 * * *$ & $0.0007 * *$ & NS & NS & $-0.0005^{*}$ & NS & NS \\
\hline$T_{\text {outlet }}\left({ }^{\circ} \mathrm{C}\right)$ & NS & $0.0020 * *$ & NS & NS & $-0.0013^{*}$ & NS & NS \\
\hline$\Delta T_{\text {air }}^{2}\left({ }^{\circ} \mathrm{C}\right)$ & $-0.0608 * * *$ & NS & NS & $0.0005^{*}$ & NS & NS & NS \\
\hline$T_{\text {droplet }}{ }^{3}\left({ }^{\circ} \mathrm{C}\right)$ & $-0.4247 * * *$ & $0.0061 *$ & NS & NS & $-0.0044 *$ & NS & NS \\
\hline$\Delta T_{\text {droplet }}^{4}\left({ }^{\circ} \mathrm{C}\right)$ & NS & $0.0023 * *$ & $0.0024 *$ & NS & NS & NS & NS \\
\hline $\mathrm{RDK}^{5}(\%)$ & NS & $0.1393 * *$ & $0.1429 *$ & NS & NS & NS & NS \\
\hline Feeding rate & NS & NS & NS & NS & NS & NS & NS \\
\hline
\end{tabular}

${ }^{1}$ Significance: NS, not significant, $* P<0.1 ; * * P<0.05 ; * * * P<0.001$.

${ }^{2} \Delta T_{\text {air }}=T_{\text {inlet }}-T_{\text {outlet. }}$.

${ }^{3}$ Theoretical wet temperature of the drying droplet, calculated from the enthalpic diagram for an absolute humidity of $1 \mathrm{~g} \cdot \mathrm{kg}^{-1}$ of water in dry air.

${ }^{4} \Delta T_{\text {droplet }}=T_{\text {outlet }}-T_{\text {droplet }}$.

${ }^{5} \mathrm{RDK}=\Delta T_{\text {droplet }} /$ maximum $\Delta T_{\text {droplet. }}$.

${ }^{6}$ Volume-weighed diameter $d_{43}$ in the rehydrated powders.

influence of spray-drying conditions on free fat formation in fat-filled dairy powders.

The free fat content was affected by drying air temperatures, not by drying kinetics. It significantly decreased from $12.8 \%$ to $8.8 \%$ of the total fat content $(-45 \%)$ when $T_{\text {inlet }}$, $\Delta T_{\text {air }}$ and $T_{\text {droplet }}$ increased, whatever the feeding rates to the spray-drying chamber (Tab. II). The trend was not significant with $T_{\text {outlet }}$. Consequently, the free fat content was not correlated with $\Delta T_{\text {droplet }}$ nor with RDK.

\subsection{Surface fat increases with increasing drying air temperatures and faster kinetics}

The surface fat area was obtained in situ at the extreme surface of powder particles, from XPS measurements. Surface composition is expected to depend on spray-drying conditions.

The surface composition was significantly affected by drying air temperatures and kinetics. Results are presented in Table I and statistical effects in Table II.

Fat covered $12-19 \%$, protein $53-58 \%$ and lactose $27-29 \%$ of the surface area of powder particles. The surface composition of the powder particles was drastically different from their bulk composition. It means that there was a redistribution of fat, protein and lactose during the spraydrying process. Both fat and protein were overrepresented at the surface of powder particles, in comparison with their mass concentration in bulk, in the powder (100 and $135 \mathrm{~g} \cdot \mathrm{kg}^{-1}$ in dry matter, respectively, vs. $765 \mathrm{~g} \cdot \mathrm{kg}^{-1}$ in dry matter for lactose). Surface fat area significantly increased when $T_{\text {inlet, }}, T_{\text {outlet }}, T_{\text {droplet, }} \Delta T_{\text {droplet }}$ and RDK increased. It was not affected by $\Delta T_{\text {air }}$ Surface protein area varied conversely; it significantly decreased when $T_{\text {inlet, }}, T_{\text {outlet }}$ and $T_{\text {droplet }}$ increased. It was not affected by $\Delta T_{\text {air }}, \Delta T_{\text {droplet }}$ and RDK. Surface lactose was not affected by spraydrying conditions. This result is consistent 


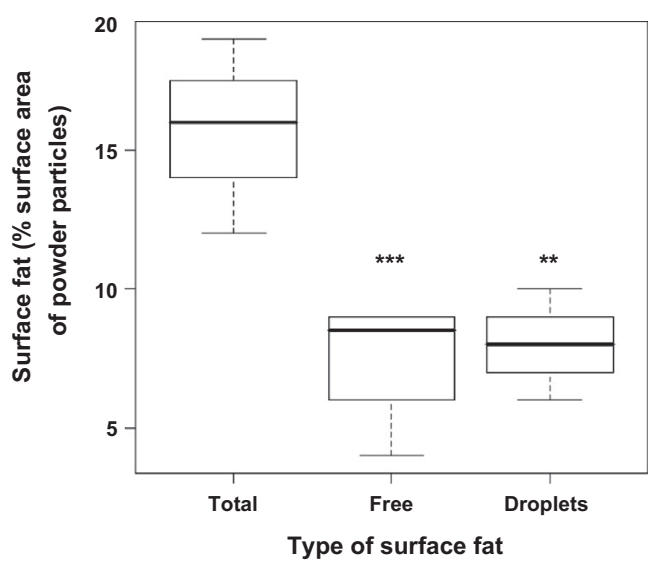

Figure 1. Box plot of the type of fat present at the surface of powder particles. Significance: $* * P<0.01$ and $* * * P<0.005$.

with the non-surface-active property of lactose.

Surface fat was further investigated by measuring the surface composition of powder particles after free fat extraction with petroleum ether. Only fat droplets were assumed to be measured by XPS after free fat removal, and the difference was attributed to surface free fat. Figure 1 shows a significant decrease in surface fat after free fat extraction $(P<0.01)$. On average, surface fat was composed of half free fat and half fat droplets. Surface free fat tended to increase when $\Delta T_{\text {droplet }}$ and RDK increased (Tab. II). Surface fat droplets tended to increase when $\Delta T_{\text {air }}$ increased. It means that fat tended to accumulate at the surface of drying droplets, when drying air temperatures were high and drying kinetics were fast.

Surface free fat had firstly been quantified by Kim et al. [21], after a quick washing with petroleum ether. However, in this study, XPS was favored to indirectly characterize surface free fat in situ, in the powder. It was a more accurate method to detect small amounts of surface free fat, provided powder particles in aggregates did not tend to be individualized after free fat removal [37].

\subsection{Fat droplet size is not affected by drying air temperatures and kinetics}

Fat droplet sizes were compared before and after spray drying using laser light scattering, in order to detect possible dissimilarities related to spray-drying conditions. In our protocol for fat droplet size measurements in rehydrated powders, sampling was realized under the potential free fat layer, in order to avoid the presence of non-globular fat in the circulating cell [37].

The size distribution of fat droplets was bimodal in both emulsions and rehydrated powders, for measurements in water with EDTA to dissociate casein micelles (Fig. 2A). Their diameter ranged from 0.036 to $2.8 \mu \mathrm{m}$. The first mode was centered on $0.24 \mu \mathrm{m}$ and the second mode on $0.49 \mu \mathrm{m}$. Figure 2B supports the likeness of size distribution between the initial emulsion and a rehydrated powder. Size distributions and modes were similar in the emulsions and rehydrated powders in water with SDS and EDTA (Fig. 2C).

The $d_{43}$ value was used in order to detect more accurately differences between the samples (white squares in Fig. 2D). Indeed, 

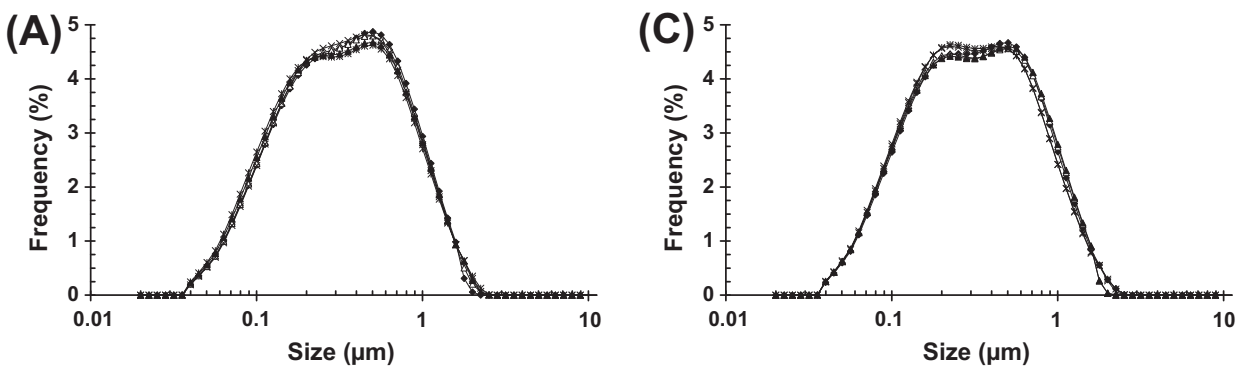

(B)
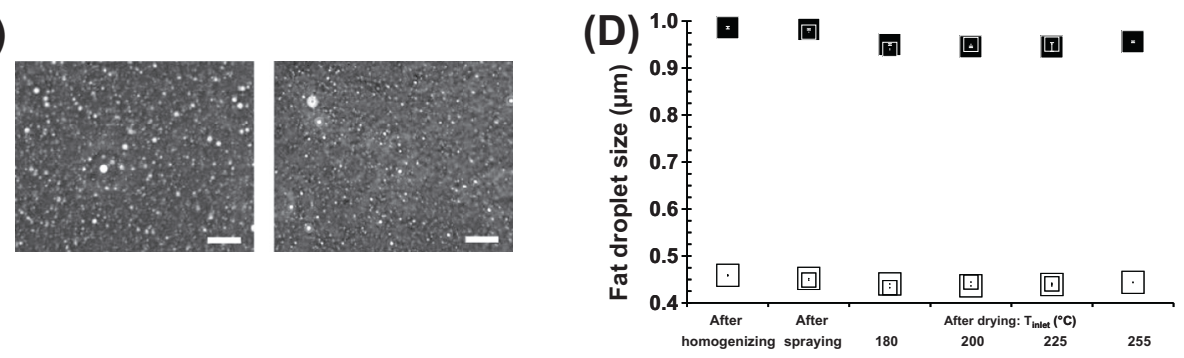

Figure 2. Fat droplet size distribution in emulsions and rehydrated powders with (A) EDTA and (C) EDTA and SDS. The symbol equivalence is: emulsion after homogenization ( $)$, emulsion after spraying with spray nozzle at a feeding rate of $1.8 \mathrm{~kg} \cdot \mathrm{h}^{-1}(\triangle)$ and $3.0 \mathrm{~kg} \cdot \mathrm{h}^{-1}(\boldsymbol{\Delta})$, rehydrated powders dried at inlet air temperature of $180{ }^{\circ} \mathrm{C}(\times)$ and $255^{\circ} \mathrm{C}(*)$. (B) Phase-contrast light micrographs in the initial emulsion (left) and in a rehydrated powder (right). Scale bar $=10 \mu \mathrm{m}$. (D) Volume-weighted diameters $d_{43}(\square)$ and $d(0.9)$ ( $\square$ ) in emulsions and rehydrated powders with EDTA and SDS, as a function of processing step and feeding rate to the spray-drying chamber: $1.8 \mathrm{~kg} \cdot \mathrm{h}^{-1}$ (small symbols) and $3.0 \mathrm{~kg} \cdot \mathrm{h}^{-1}$ (large symbols). $n=6$.

the $d_{43}$ is sensitive to larger particles. It slightly decreased after spraying with spray nozzle and again after spray drying, but it remained in a narrow range of values (0.43-0.46 $\mu \mathrm{m})$.

The $d(0.9)$ was $0.98 \mu \mathrm{m}$ in emulsions and $0.94-0.95 \mu \mathrm{m}$ in rehydrated powders (dark squares in Fig. 2D). Fat droplet sizes below $1 \mu \mathrm{m}$ are known to favor emulsion stability and enhance fat retention, as determined in previous studies [32, 39]. It means that $90 \%$ of the total volume of fat droplets were fat droplets smaller than the critical size. As a consequence, despite their bimodal size distribution, fat droplets were assumed to be stable in size through the process, when considering the fraction of globular fat in the rehydrated powders.
These observations had two consequences. Firstly, there was no aggregation of fat droplets in the initial emulsions, i.e. individualized fat droplets underwent spray drying. Secondly, spraying with spray nozzle and spray drying did not lead to coalescence nor aggregation between fat droplets, whatever the tested drying air temperatures and kinetics. In statistical terms, fat droplet size and fat droplet aggregation were not significantly affected by spray-drying parameters (Tab. II).

Interestingly, size distribution of fat droplets was not significantly affected by the tested feeding rates (which varied to adjust the $T_{\text {outlet }}$ ). Shearing forces may have been different with $1.8 \mathrm{vs} .3 \mathrm{~kg} \cdot \mathrm{h}^{-1}$, when the emulsion flowed through pipes toward 

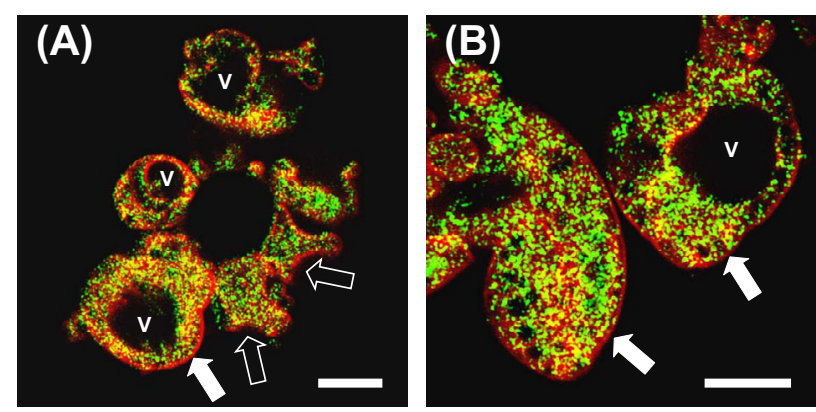

Figure 3. Confocal laser scanning micrographs of powder particles dried at inlet air temperature of (A) $180{ }^{\circ} \mathrm{C}$ and (B) $255^{\circ} \mathrm{C}$. V stands for vacuole. White arrows indicate the surface protein layer, and empty arrows indicate the shriveled surface of powder particles. Scale bar: $5 \mu \mathrm{m}$.

the spray-drying chamber. The Reynolds number indicated that the flow was laminar in both cases; then, the shearing forces increased proportionally to the feeding rate. Shearing forces are known to affect fat droplet size [40]. However, in our experiments, they were probably too weak to further disrupt the very small fat droplets.

\subsection{Microstructural observations of fat in powder particles}

The supramolecular structure of fat was characterized with CLSM in situ in the powder particles. Qualitative differences in fat supramolecular structure were expected in relation to the spray-drying conditions, given the above-mentioned quantitative results.

Micrographs are presented for the powders dried at extreme $T_{\text {inlet }}$, such as 180 and $255^{\circ} \mathrm{C}$, because $T_{\text {inlet }}$ was found to be the most significant spray-drying parameter. It corresponds to a $\Delta T_{\text {droplet }}$ of 35 and $52{ }^{\circ} \mathrm{C}$, and an RDK of $58 \%$ and $87 \%$, respectively. In other words, the second powder is supposed to be dried 1.5 times faster than the first powder.

Fat was located both at the surface and the inner parts of the powder particles, as small fat droplets encapsulated in a protein matrix (Figs. 3A and 3B). No free fat layer nor patches were observed probably because their size was too small to be detected by CLSM as already noticed in one of our previous studies [37]. No lactose crystals were observed by phase contrast.

Large vacuoles (V) were present inside the powder particles.

Fat and protein were not homogeneously distributed at the surface of powder particles: protein was the main component (white arrows). This observation supports the XPS measurements. Moreover, fat and protein were not homogeneously distributed within the powder particles too, in the powder dried with the lower $T_{\text {inlet }}$.

These observations indicate a redistribution of components during spray drying. It concerns the surface of power particles and also their inside parts when $T_{\text {inlet }}$ is low.

Interestingly, a few particles underwent more shrinkage when $T_{\text {inlet }}$ was low (empty arrows in Fig. 3A). The formation of surface indentations has been attributed to shrinkage of casein and uneven drying of powder particles at early stages of spray drying $[6,32]$, and to the presence of high levels of protein [8]. Our XPS measurements are consistent with this last statement.

Shrinkage may cause dramatic changes in fat supramolecular structure, both at the surface and within the powder particle. It is consistent with the higher free fat contents found in these powders. In the case of 
surface composition, it is worth wondering to what extent XPS is a relevant method. Indeed, the analyzed area is assumed to be flat and the emission angle of photoelectrons is assumed to be perpendicular to the powder sample. The curved surface of powder particles is known to vary the emission angle of photoelectrons and decrease the analysis depth [4, 11], even if the analysis depth (about $10 \mathrm{~nm}$ ) is negligible compared to the analyzed area (ellipsis of $300 \mu \mathrm{m}$ wide by $700 \mu \mathrm{m}$ long). An irregular surface would affect the XPS measurements.

\subsection{Proposed mechanisms}

Fat supramolecular structure in fat-filled dairy powders largely depends on spray-drying conditions. This section provides selected clues about the possible mechanisms.

In the present study, the inlet air temperature was corrected by considering the estimated energetic losses. Moreover, the feeding rate to the spray-drying chamber was controlled, a larger range of drying conditions was tested and a spray nozzle was used instead of a centrifugal atomizer in the study by Kim et al. [24]. The emulsion was prepared with sunflower oil which was liquid during all the processing steps because of its low melting point (about $5{ }^{\circ} \mathrm{C}$ ). This mobile fluid state was favored in order to (i) maximize oil leakage onto the surface of powder particles, as suggested for milk fat by Fäldt and Bergenståhl [9] and Nijdam and Langrish [30], and (ii) avoid the mechanical damage of fat droplets which is usually associated with the presence of fat crystals [40]. Fat droplet size, free fat and surface fat were characterized both after sample preparation and in situ.

Free fat was detected in all the powders, whatever the spray-drying conditions. What are the mechanisms underlying free fat creation?

The hypothesis is the main formation of free fat during spray drying and little during storage, given that it was detected only $48 \mathrm{~h}$ after the manufacture of the powders. However, it was detected by the solvent extraction method only, neither by laser light scattering nor by confocal microscopy. As explained before, fat droplet size measurements only concerned the fraction of globular fat in the rehydrated powders. A top free fat layer could be expected when rehydrating the samples. It was not observed because of the very small amount of free fat, i.e. $\sim 0.002 \mathrm{~g} \cdot \mathrm{kg}^{-1}$ in the rehydrated powders (for a total solids content of $200 \mathrm{~g} \cdot \mathrm{kg}^{-1}$ ). Nevertheless, if the fraction of globular fat was not significantly affected by spray-drying temperatures, a small fraction could have been destabilized and led to the creation of free fat. Moreover, the resolution of CLSM did not reveal the presence of free fat: the hypothesis is that the surface free fat layer is too thin and the free fat patches too small to be detected by this technique.

Free fat could originate from a physical damage due to the physical state of components in the drying droplet, namely fat and lactose crystals. $T_{\text {droplet }}$ ranged from 45 to $53{ }^{\circ} \mathrm{C}$, i.e. above the final melting point of sunflower oil (about $5{ }^{\circ} \mathrm{C}$ ): no fat crystals were present during drying. Moreover, drying kinetics were too fast and the initial lactose content was too low $\left(153 \mathrm{~g} \cdot \mathrm{kg}^{-1}\right.$ in the emulsion to dry) to allow the creation of lactose crystals in the drying droplet. Fat droplet size was very small all along the process: fat droplets were unlikely to break out during drying, under the combined effect of air temperature and pressure. However, $T_{\text {inlet }}$ had a significant influence on the free fat content. This finding suggests a fast dry crust formation at the boundary parts of the powder particles when $T_{\text {inlet }}$ is high. Hence, there would be less time for fat migration and collision of fat droplets during drying, which would prevent the disruption and coalescence of fat droplets. Free fat quantification supports this hypothesis, not surface free fat evaluation because another mechanism was involved in this 


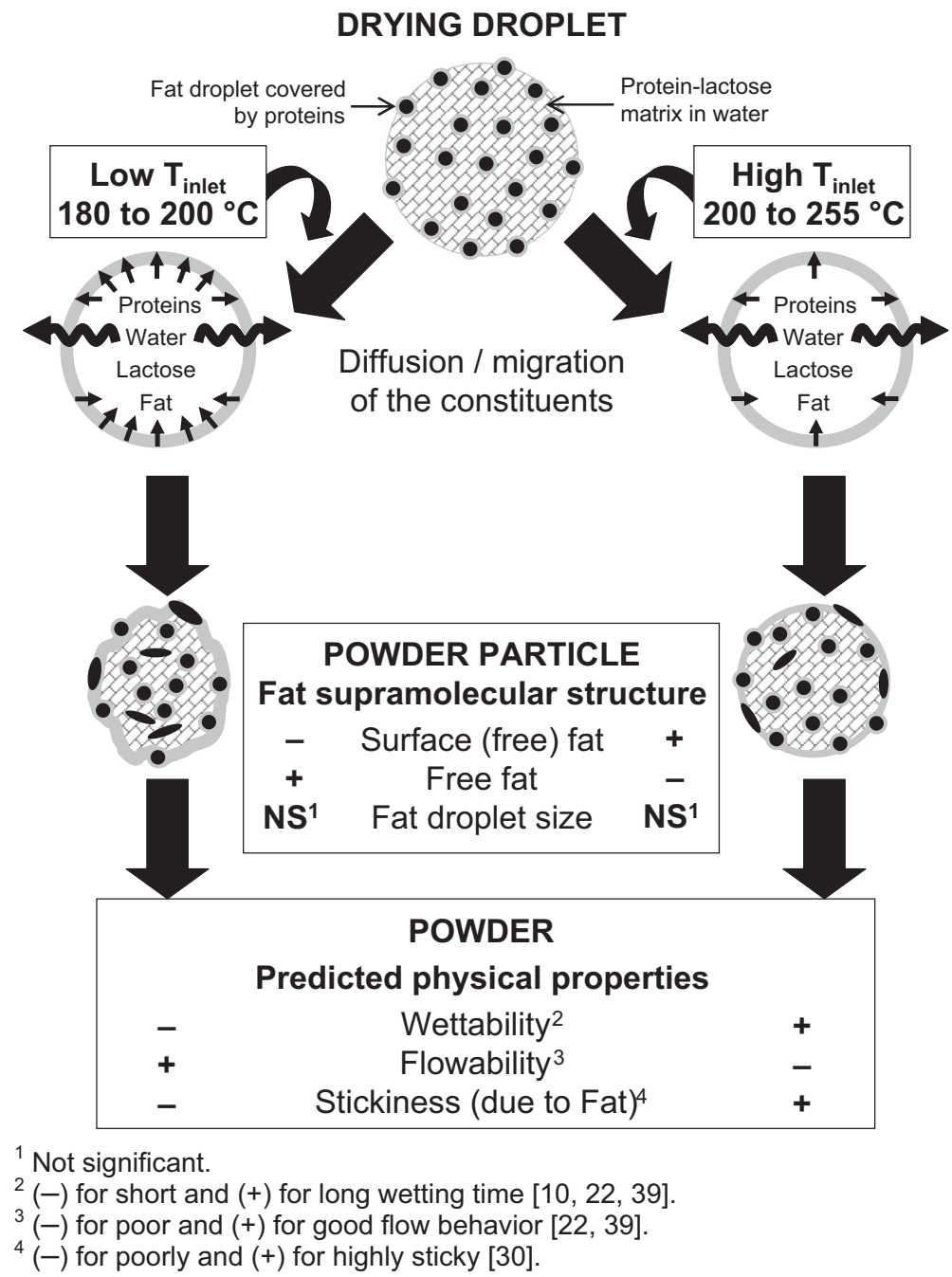

Figure 4. Possible mechanisms leading to fat supramolecular structure in fat-filled dairy powders.

case (discussed later in this section). Kim et al. [24] had previously made this hypothesis with different spray-drying conditions: drying air temperatures corresponding to our lower $T_{\text {inlet }}$ and $T_{\text {outlet }}$ (even if not corrected by energy losses), smaller feeding rate (not considered as a parameter of influence) and centrifugal atomizer.
Fat and protein were overrepresented at the surface of powder particles, whatever the spray-drying conditions. What are the mechanisms underlying the formation of the surface composition?

When the preparation is sprayed through spray nozzle, protein tends to diffuse and accumulate at the air-drying droplet interface 
because of their surface-active properties [40]. More details can be found in the thorough review by Jayasundera et al. [16]. Nijdam and Langrish [30] showed that protein accumulates at the surface of the drying droplet at the expense of lactose during spray drying. On the other hand, the authors postulated that higher air temperatures accelerate the formation of a surface skin, which hinders the migration of surface-active protein toward the surface. Hence, with high $T_{\text {inlet }}$, less redistribution of protein was observed at the surface of our powder samples; nevertheless, surface protein was high and resulted in a surface composition not similar to the bulk one, as it could be expected.

Overrepresentation of fat has been already observed and attributed to a slower migration of free fat and the large fat droplets toward the interior of the drying droplet while water vaporizes [20]. If the formation of the dry crust is fast, there would be more fat at the surface of powder particles. This is the case in our powder samples, for both surface free fat and surface fat droplets. Moreover, Hogan et al. [15] showed that the presence of fat at the drying droplet surface could hinder the crust or skin formation. However, it did not seem to be the main phenomenon implied for our powder samples.

The shrinkage of a few particles, when $T_{\text {inlet }}$ is low, indicates that the surface skin remained moist and supple for longer so that the hollow particle can deflate and shrivel as it cooled [24, 30]. This finding also supports the greater component redistribution observed in our powder samples with low $T_{\text {inlet }}$.

Hence, the most reliable hypothesis is a redistribution of components at the early stage of spray drying, i.e. before the formation of a dry crust or skin at the surface of powder particles, which would determine fat supramolecular structure in fat-filled dairy powders.

Figure 4 is a schematic representation of the above-discussed mechanisms. It was completed by the powder physical properties usually attributed to these fat supramolecular structures, in the literature and in our previous works [39].

\section{CONCLUSION}

Fat supramolecular structure in fat-filled dairy powders was significantly affected by spray-drying conditions. The free fat content decreases with increasing drying air temperatures. Surface fat increases with increasing drying air temperatures and faster kinetics. Only fat droplet size was not affected by spray-drying conditions: the small fat droplets were stable in size through the process with the tested parameters.

Inlet air temperature and consequently temperature of the drying droplet had the most significant influence. Hence, we proposed a possible mechanism where the formation of fat supramolecular structure in fat-filled dairy powders was attributed to a redistribution of components at the early stage of spray drying. The involved mechanisms would be mainly the diffusion of surface-active protein to the air-drying droplet interface and the formation of a dry crust or skin at the surface of powder particles. This study highlights the importance of studying drying air temperatures and kinetics to elucidate the mechanisms of free fat formation and the presence of fat at the surface of powder particles.

From a reverse point of view, the proposed mechanisms can be used as a tool to adjust spray-drying temperatures and kinetics, in order to obtain well-characterized structures of fat. As an example, this study shows that middle range inlet air temperature should be optimal in order to limit both free and surface fat. Furthermore, controlling the structure of fat using spray-drying conditions is essential to direct powder physical properties such as rehydration, flowability and oxidative stability. 
Further investigations could include the study of a different oil (composition: fatty acids, amphiphilic molecules and crystallization properties) and the evolution of fat supramolecular structure during storage.

Acknowledgements: The authors are indebted to Bretagne Biotechnologies Alimentaires (BBA, Rennes, France) for stimulating discussions and financial support. Mr. Jacques Lambert (UMR 7564 LCPME, CNRS-Nancy-Université Nancy, France) and Dr. Daniel Sangermani (Centre for Advanced Light Microscopy, The School of Biomedical Sciences, University of Queensland, St. Lucia, Australia) are acknowledged for technical support and valuable discussions on surface analysis and confocal microscopy, respectively.

\section{REFERENCES}

[1] Aguilar C.A., Ziegler G.R., Physical and microscopic characterization of dry whole milk with altered lactose content. 2. Effect of lactose crystallization, J. Dairy Sci. 77 (1994) 1198-1204.

[2] AttaieH., Breitschuh B., Braun P., WindhabE., The functionality of milk powder and its relationship to chocolate mass processing, in particular the effect of milk powder manufacturing and composition on the physical properties of chocolate masses, Int. J. Food Sci. Technol. 38 (2003) 325-335.

[3] Bhandari B.R., Dumoulin E.D., Richard H.M.J., Noleau I., Lebert A.M., Flavor encapsulation by spray drying - application to citral and linalyl acetate, J. Food Sci. 57 (1992) 217-221.

[4] Briggs D., Rivière J.C., Spectral interpretation, in: Briggs D., Seah M.P. (Eds.), Practical Surface Analysis, Volume 1 - Auger and X-ray Photoelectron Spectroscopy, John Wiley \& Sons Ltd., Chichester, UK, 1990, pp. 85-141.

[5] Buma T.J., Free fat in spray-dried whole milk. 10. A final report with a physical model for free-fat in spray-dried milk, Neth. Milk Dairy J. 25 (1971) 159-174.

[6] Buma T.J., Henstra S., Particle structure of spray-dried milk products as observed by a scanning electron microscope, Neth. Milk Dairy J. 25 (1971) 75-80.
[7] De Vilder J., Martens R., Naudts M., Influence of process variables on some whole milk powder characteristics, Milchwissenschaft 31 (1976) 396-401.

[8] Fäldt P., Bergenståhl B., The surface composition of spray-dried protein-lactose powders, Colloids Surf. A: Physicochem. Eng. Aspects 90 (1994) 183-190.

[9] Fäldt P., Bergenståhl B., Fat encapsulation in spray-dried food powders, J. Am. Oil Chem. Soc. 72 (1995) 171-176.

[10] Fäldt P., Bergenståhl B., Spray-dried whey protein/lactose/soybean oil emulsions. 2. Redispersability, wettability and particle structure, Food Hydrocoll. 10 (1996) 431-439.

[11] Fäldt P., Bergenståhl B., Carlsson G., The surface coverage of fat on food powders analyzed by ESCA (electron spectroscopy for chemical analysis), Food Struct. 12 (1993) 225-234.

[12] Fuchs M., Turchiuli C., Bohin M., Cuvelier M.E., Ordonnaud C., Peyrat-Maillard M.N., Dumoulin E., Encapsulation of oil in powder using spray drying and fluidised bed agglomeration, J. Food Eng. 75 (2006) 27-35.

[13] Gaiani C., Ehrhardt J.J., Scher J., Hardy J., Desobry S., Banon S., Surface composition of dairy powders observed by X-ray photoelectron spectroscopy and effects on their rehydration properties, Colloids Surf. B: Biointerfaces 49 (2006) 71-78.

[14] Granelli K., Fäldt P., Appelqvist L.A., Bergenståhl B., Influence of surface structure on cholesterol oxidation in model food powders, J. Sci. Food Agric. 71 (1996) 75-82.

[15] Hogan S.A., McNamee B.F., O’Riordan E.D., O'Sullivan M., Microencapsulating properties of whey protein concentrate 75 , J. Food Sci. 66 (2001) 675-680.

[16] Jayasundera M., Adhikari B., Aldred P., Ghandi A., Surface modification of spray dried food and emulsion powders with surface-active proteins: a review, J. Food Eng. 93 (2009) 266-277.

[17] Kelly J., Kelly P.M., Harrington D., Influence of processing variables on the physicochemical properties of spray dried fat-based milk powders, Lait 82 (2002) 401-412.

[18] Keogh M.K., O'Kennedy B.T., Kelly J., Auty M.A.E., Kelly P.M., Fureby A., Haahr A., Stability to oxidation of spray-dried fish oil 
powder microencapsulated using milk ingredients, J. Food Sci. 66 (2001) 217-224.

[19] Keogh M.K., Twomey M., O'Kennedy B.T., Mulvihill D., Effect of milk composition on spray-dried high-fat milk powders and their use in chocolate, Lait 82 (2002) 531-539.

[20] Kim E.H.J., Chen X.D., Pearce D., On the mechanisms of surface formation and the surface compositions of industrial milk powders, Drying Technol. 21 (2003) 265-278.

[21] Kim E.H.J., Chen X.D., Pearce D., Melting characteristics of fat present on the surface of industrial spray-dried dairy powders, Colloids Surf. B: Biointerfaces 42 (2005) 1-8.

[22] Kim E.H.J., Chen X.D., Pearce D., Effect of surface composition on the flowability of industrial spray-dried dairy powders, Colloids Surf. B: Biointerfaces 46 (2005) 182-187.

[23] Kim E.H.J., Chen X.D., Pearce D., Surface composition of industrial spray-dried milk powders. 1. Development of surface composition during manufacture, J. Food Eng. 94 (2009) 163-168.

[24] Kim E.H.J., Chen X.D., Pearce D., Surface composition of industrial spray-dried milk powders. 2. Effects of spray drying conditions on the surface composition, J. Food Eng. 94 (2009) 169-181.

[25] Kim E.H.J., Chen X.D., Pearce D., Surface composition of industrial spray-dried milk powders. 3. Changes in the surface composition during long-term storage, J. Food Eng. 94 (2009) 182-191.

[26] Labrousse S., Roos Y.H., Karel M., Collapse and crystallization in amorphous matrices with encapsulated compounds, Sci. Aliments 12 (1992) 757-769.

[27] Liang B., Hartel R.W., Effects of milk powders in milk chocolate, J. Dairy Sci. 87 (2004) 20-31.

[28] Lopez C., Focus on the supramolecular structure of milk fat in dairy products, Reprod. Nutr. Dev. 42 (2005) 497-511.

[29] McKenna A.B., Lloyd R., Munro P., Singh H., Microstructure of whole milk powder and of insolubles detected by powder functional testing, Scanning 21 (1999) 305-315.

[30] Nijdam J.J., Langrish T.A.G., The effect of surface composition on the functional properties of milk powders, J. Food Eng. 77 (2006) 919-925.
[31] Özkan N., Walisinghe N., Chen X.D., Characterization of stickiness and cake formation in whole and skim milk powders, J. Food Eng. 55 (2002) 293-303.

[32] Rosenberg M., Young S.L., Whey proteins as microencapsulating agents. Microencapsulation of anhydrous milkfat - structure evaluation, Food Struct. 12 (1993) 31-41.

[33] Schuck P., Piot M., Mejean S., Fauquant J., Brulé G., Maubois J.L., Déshydratation des laits enrichis en caséine micellaire par microfiltration ; comparaison des propriétés des poudres obtenues avec celles d'une poudre de lait ultra-propre [Dehydratation of an ultra-clean milk and micellar casein enriched milks], Lait 74 (1994) 47-63.

[34] Sloth Hansen P., Production of agglomerated fat-filled powder, J. Soc. Dairy Technol. 33 (1980) 19-23.

[35] Tamsma A., Edmondson L.F., Vettel H.E., Free-fat in foam dried whole milk, J. Dairy Sci. 42 (1959) 240-250.

[36] Vignolles M.L., Jeantet R., Lopez C., Schuck P., Free fat, surface fat and dairy powders: interactions between process and product. A review, Lait 87 (2007) 187-236.

[37] Vignolles M.L., Lopez C., Ehrhardt J.J., Lambert J., Méjean S., Jeantet R., Schuck P., Methods' combination to investigate the suprastructure, composition and properties of fat in fat-filled dairy powders, J. Food Eng. 94 (2009) 154-162.

[38] Vignolles M.L., Lopez C., Madec M.N., Ehrhardt J.J., Méjean S., Schuck P., Jeantet R., Protein-lactose matrix effects on fat encapsulation during the overall spray-drying process of dairy powders, Aust. J. Dairy Technol. 64 (2009) 75-79.

[39] Vignolles M.L., Lopez C., Madec M.N., Ehrhardt J.J., Méjean S., Schuck P., Jeantet R., Fat properties during homogenization, spraydrying, and storage affect the physical properties of dairy powders, J. Dairy Sci. 92 (2009) 58-70.

[40] Walstra P., Jenness R., Milk fat globules, in: Walstra P., Jenness R. (Eds.), Dairy Chemistry and Physics, John Wiley \& Sons, New York, USA, 1984, pp. 254-300.

[41] Zhu P., Jeantet R., Dolivet A., Méjean S., Schuck P., Caractérisation du comportement d'une tour de séchage pilote: bilans massiques et thermiques [Characterization of a spray-drying pilot plant in relation to mass and energy balances and to quality of the obtained powders], Ind. Alim. Agr. 126 (2009) 23-29. 